\title{
ECONOMICA
}

Journal of Economic and Economic Education Vol.1 No.2 (175-182)

\section{PENGARUH KOMITMEN ORGANISASI DAN KOMPENSASI TERHADAP KEPUASAN KERJA KARYAWAN PADA CV. LAKITAN PADANG}

\author{
Rizky Natassia \\ Dosen Program Studi Pendidikan Ekonomi STKIP- PGRI Sumbar \\ Jl. Gunung Pangilun No.1, Padang Sumatera Barat. \\ Email: Rizkynatassia@gmail.com \\ submited: 2013.01.16 reviewed: 2013.03.18 accepted: 2013.04 .29 \\ http://dx.doi.org/10.22202/economica.2013.v1.i2.117
}

\begin{abstract}
This study aims to measure the effect of organizational commitment on job satisfaction and employee compensation. Data collection techniques using sampling that is numbered 35 total employees. Method of data collection is using questionnaires. Filling the questionnaire sought only takes 15 minutes so it was not so timeconsuming respondents. The variables used in this study are the commitment of the organization and compensation as the independent variable, while the dependent variable is employee satisfaction. The method of analysis used is multiple linear regression method was used to determine whether or not the influence of the independent variables with the dependent variable. Organizational Commitment variable has a positive effect $(\beta$ $=0.089)$ and significant $(\alpha=0.019)$ on employee satisfaction. Compensation variable has a positive effect $(\beta=$ $0.078)$ and significant $(\alpha=0.028)$ towards employee satisfaction
\end{abstract}

\begin{abstract}
Abstrak
Penelitian ini bertujuan untuk mengukur pengaruh komitmen organisasi terhadap kepuasan kerja dan kompensasi karyawan. Teknik pengumpulan data menggunakan sampel yang berjumlah 35 karyawan total. Metode pengumpulan data menggunakan kuesioner. Mengisi kuesioner dicari hanya membutuhkan waktu 15 menit sehingga tidak begitu responden memakan waktu. Variabel yang digunakan dalam penelitian ini adalah komitmen organisasi dan kompensasi sebagai variabel independen, sedangkan variabel terikat adalah kepuasan karyawan. Metode analisis yang digunakan adalah metode regresi linier berganda digunakan untuk menentukan apakah atau tidak pengaruh variabel independen dengan variabel dependen. variabel Komitmen organisasi memiliki efek positif $(\beta=0,089)$ dan signifikan $(\alpha=0,019)$ pada kepuasan karyawan. variabel kompensasi memiliki efek positif $(\beta=0,078)$ dan signifikan $(\alpha=0,028)$ terhadap kepuasan karyawan.
\end{abstract}

Keywords: Commitmen, Satisfaction, simple regression 


\section{PENDAHULUAN}

Dalam menjalankan kegiatan usahanya, suatu perusahaan akan membutuhkan berbagai sumber daya, seperti modal, material dan mesin. Perusahaan juga membutuhkan sumber daya manusia, yaitu para karyawan. Karyawan merupakan sumber daya yang penting bagi perusahaan, karena memiliki bakat, tenaga dan kreativitas yang sangat dibutuhkan oleh perusahaan untuk mencapai tujuannya. Sebaliknya, sumber daya manusia juga mempunyai berbagai macam kebutuhan yang ingin dipenuhinya. Untuk mencapai produktivitas kerja karyawan yang tinggi maka perusahaan harus memperhatikan kepuasan kerja karyawannya. Kepuasan Kerja menurut Luthans (2005) dalam bukunya Organizational Behaviour mengutip pendapat Locke bahwa kepuasan kerja merupakan keadaan emosional yang positif dari seseorang yang ditimbulkan dari penghargaan atas sesuatu pekerjaan yang telah dilakukannya. Dikatakan lebih lanjut bahwa kepuasan kerja merupakan hasil dari prestasi seseorang terhadap sampai seberapa baik pekerjaannya menyediakan sesuatu yang berguna baginya.

Kepuasan kerja karyawan dapat dipengaruhi oleh komitmen yang dimiliki oleh karyawan terhadap organisasi ditempatnya bekerja. Kepuasan kerja didefinisikan sebagai perasaan senang atau tidak senang (favorable or infavorahle) seseorang berkenaan dengan pekerjaannya (Davis dan Newstrom, 2001:105) atau sikap seseorang secara umum terhadap pekerjaannya (Robbins, 2001:147). Berdasarkan pengertian tersebut, dapat disimpulkan bahwa kepuasan kerja merupakan variabel sikap (attitude), yang berkaitan dengan perasaan karyawan terhadap pekerjaannya.

Disamping di pengaruhi oleh komitmen organisasi, kepuasan kerja dapat dipengaruhi oleh tingkat kompensasi yang diberikan oleh perusahaan kepada karyawannya. Kompensasi merupakan sejumlah uang atau penghargaan yang diberikan oleh suatu organisasi atau perusahaan kepada karyawannya,sebagai imbalan atas jasanya dalam melakukan tugas, kewajiban dan tanggung jawab

yang dibebankan kepadanya yang digunakan untuk memenuhi kebutuhan hidupnya. Bagi sebagian karyawan, harapan untuk mendapatkan uang adalah satu-satunya alasan untuk bekerja, namun yang lain berpendapat bahwa uang hanyalah salah satu dari banyak kebutuhan yang terpenuhi melalui kerja. Seseorang yang bekerja akan merasa lebih dihargai oleh masyarakat di sekitarnya, dibandingkan yang tidak bekerja. Mereka akan merasa lebih dihargai lagi apabila menerima berbagai fasilitas dan simbolsimbol status lainnya dari perusahaan dimana mereka bekerja. Dari uraian di atas dapat dikatakan,

bahwa kesediaan karyawan untuk mencurahkan kemampuan, pengetahuan, keterampilan, tenaga, dan waktunya, sebenarnya mengharapkan adanya imbalan dari pihak perusahaan yang dapat memuaskan kebutuhannya.

Bisnis industri hasil bumi di kota Padang cukup marak, hal ini dibuktikan dengan banyaknya bermunculan perusahaan eksprotir hasil bumi diantaranya : CV. Pinang Emas, CV. Natraco, CV. Rasdi \& Co, CV. Rempah Sari. CV. Lakitan merupakan salah satu bentuk perusahaan yang bergerak dibidang ekspor-import hasil bumi yang tidak luput dari persaingan bisnis. Sebagai perusahaan yang bergerak di bidang eksport-import banyak hal yang perlu dilakukan oleh CV. agar mampu berkompetisi dengan perusahaan lainnya di kota Padang pada khususnya. Dalam menjalankan kegiatan operasionalnya, maka perusahaan harus memperhatikan aspek sumber daya manusia dalam hal ini adalah karyawan. Perusahaan harus memperhatikan tingkat kepuasan, komitmen organisasi dan kompensasi yang diberikan kepada karyawannya dalam rangka mencapai tujuan perusahaan. 
Berdasarkan uraian dari latar belakang diatas, maka permasalahan yang dibahas dalam penelitian ini adalah, bagaimana pengaruh Komitmen organisasi dan kompensasi terhadap kepuasan karyawan pada CV. Lakitan.

\section{Kepuasan Kerja}

Kepuasan Kerja dapat diartikan sebagai suatu sikap yang dirasakan oleh karyawan terhadap pekerjaannya, disini dapat dilihat bahwa kepuasan kerja yang dirasakan oleh karyawan adalah ketika karyawsan menyikapi pekerjaan yang diberikan kepadanya. Kepuasan kerja akan mencerminkan perasaan senang atau tidak senang dalam pekerjaan, jadi Kepuasan kerja atau job satisfaction adalah keadaan emosional yang menyenangkan atau tidak menyenangkan dengan mana para karyawan memandang pekerjaannya (Handoko, 1992; 193). Kepuasan kerja merupakan cerminan dari perasaan pekerja terhadap pekerjaannya. Hal ini tampak dalam sikap positif pekerja terhadap pekerjaan yang dihadapi dan lingkungannya. Sebaliknya, karyawan yang tidak puas akan bersikap negatif terhadap pekerjaan dan bentuk yang berbeda - beda satu dengan yang lainnya. Adanya ketidakpuasan kerja karyawan seharusnya dapat dideteksi oleh perusahaan. Menurut Muchinsky (1997 ; 424), variabel-variabel yang dapat dijadikan indikasi menurunnya kepuasan kerja adalah absenteeism, turnover, and job performance.

\section{Faktor-faktor yang mempengaruhi kepuasan kerja}

Untuk dapat meningkatkan kepuasan kerja karyawan maka perusahaan harus memberikan perlakuan yang adil terhadap karyawannya, misalnya dalam system pemberian gaji yang didasarkan kepada tuntutan kerja, tingkat keterampilan individu, lingkungan kerja yang nyaman. Untuk mengetahui indikator apa saja yang mempengaruhi kepuasan kerja, menurut Luthans $(1997 ; 431)$ terdiri dari atas lima indikator, yaitu: (1) Pembayaran, seperti gaji dan upah. Karyawan menginginkan system upah dan kebijakan promosi yang dipersepsikan sebagai adil, tidak meragukan dan segaris dengan pengharapannya. Bila upah dilihat sebagai adil yang didasarkan pada tuntutan pekerjaan, tingkat ketrampilan individu, dan standar pengupahan komunitas kemungkinan besar akan dihasilkan kepuasan; (2) Pekerjaan itu sendiri. Karyawan cenderung lebih menyukai pekerjaan-pekerjaan yang memberi kesempatan untuk mengunakan kemampuan dan ketrampilannya, kebebasan, dan umpan balik mengenai betapa baik mereka bekerja. (3) Rekan kerja. Bagi kebanyakan karyawan kerja juga mengisi kebutuhan akan interaksi social, (4) Promosi pekerjaan. Promosi terjadi pada saat seorang karyawan berpindah dari suatu pekerjaan ke posisi lainnya yang lebih tinggi, dengan tanggung jawab dan jenjang organisasionalnya. Pada saat dipromosikan karyawan umumnya menghadapi peningkatan tuntutan dan keahlian, kemampuan dan tanggung jawab. Sebagian besar karyawan merasa positif karena dipromosikan, (5) Kepenyeliaan (supervisi). Supervisi mempunyai peran yang penting dalam manajemen. Supervisi berhubungan dengan karyawan secara langsung dan mempengaruhi karyawan dalam melakukan pekerjaannya.

\section{Komitmen Organisasi}

Hasibuan (2000:44) mengartikan komitmen sebagai suatu kecendrungan dalam diri seseorang untuk merasa aktif dengan penuh rasa tanggung jawab. Dengan demikian seseorang yang terlibat aktif dengan penuh tanggung jawab dalam suatu pekerjaan yang ditekuninya akan sanggup menetapkan keputusan dirinya sendirinya dan melaksanakan pekerjaan tersebut dengan kesungguhan hati.`Adanya rasa keterikatan pada suatu falsafah dan satuan kerja kemungkinan untuk bertahan dalam satuan kerja akan lebih tinggi ketimbang pegawai yang tidak'mempunyai rasa keterikatan pada satuan kerja. Shadur, 
Kinzle dan Rodwell (1999)'memberi pengertian bahwa pegawai yang mempunyai komitmen terhadap satuan`kerja menunjukkan kuatnya pengenalan dan keterlibatan pegawai dalam satuan kerja`yang dinyatakan sebagai berikut "Organizational commitement was defined as the strength of an individual's identification with and involvement in $a$ particular'organization”. Karyawan yang memiliki komitmen terhadap satuan kerja kemungkinan untuk tetap bertahan lebih tinggi dari pada karyawan yang tidak mempunyai komitmen.

Glesser dalam Hoy dan Miskey (1988:100) mengatakan bahwa bila seseorang memiliki komitmen yang tinggi, biasanya akan menunjukkan loyalitas dan kemampuan profesionalnya dan sebaliknya, bila komitmennya rendah, maka kemampuan professional dan loyalitasnya tidak akan muncul. Seseorang yang memiliki komitmen yang tinggi, biasanya menunjukkan loyalitas dan kemampuan profesionalnya, sebaliknya seseorang yang tidak memiliki komitmen dalam bekerja, prestasi, dedikasi dan loyalitas tidak akan muncul. Seorang bawahan yang loyalitasnya tinggi kepada atasan atau lembaga, biasanya menunjukkan sikap patuh, hormat dan disiplin. Ini dapat dilihat dari kehadiran, keaktifan dalam melaksanakan pekerjaannya dan ketepatan waktu dalam menyelesaikan pekerjaan, sehingga dapat menghasilkan pekerjaan yang berkualitas.

\section{Kompensasi}

Kompensasi merupakan salah satu factor penentu yang dapat mendorong kepuasan kerja karyawan. Dengan adanya pemberian kompensasi kepada karyawan baik berupa kompensasi langsung atau tidak langsung untuk meningkatkan kepuasan kerja karyawan. Pemberian kompensasi merupakan imbalan atau pembayaran untuk pekerjaan yang dilakukan oleh karyawan kepada
perusahaan.Menurut Pangabean dalam Sutrisno (2011) kompensasi adalah setiap bentuk penghargaan yang diberikan kepada karyawan sebagai balas jasa atau kontribusi yang mereka berikan kepada perusahaan.

Menurut Gomez-Mejia, et al., (1995); Schuler dan Jackson (1999); serta Luthans (1998), kompensasi total dapat diklasifikasikan dalam tiga komponen utama, yaitu: Pertama, kompensasi dasar yaitu kompensasi yang jumlahnya dan waktu pembayarannya tetap, seperti upah dan gaji. Kedua, kompensasi variabel merupakan kompensasi yang jumlahnya bervariasi dan/atau waktu pembayarannya tidak pasti. Kompensasi variabel ini dirancang sebagai penghargaan pada karyawan yang berprestasi baik. Termasuk kompensasi variabel adalah pembayaran insentif pada individu maupun kelompok, gainsharing, bonus, pembagian keuntungan (profit sharing), rencana kepemilikan saham karyawan (employee stock-ownership plans) dan stock-option plans. Ketiga, merupakan komponen terakhir dari kompensasi total adalah benefit atau seringkali juga disebut indirect compensation (kompensasi tidak langsung). Termasuk dalam komponen ini adalah (1) perlindungan umum, seperti jaminan sosial, pengangguran dan cacat; (2) perlindungan pribadi dalam bentuk pensiun, tabungan, pesangon tambahan dan asuransi; (3) pembayaran saat tidak bekerja seperti pada waktu

mengikuti pelatihan, cuti kerja, sakit, saat liburan, dan acara pribadi; (4) tunjangan siklus hidup dalam bentuk bantuan hukum, perawatan orang tua, perawatan anak, program kesehatan, dan konseling.

\section{METODOLOGI PENELITIAN}

Populasi adalah seluruh item yang akan diteliti yang akan dijadikan sebagi populasi dalam penelitian ( Sugiyono, 2012) . Dalam penelitian ini yang akan menjadi populasi adalah seluruh karyawan yang bekerja pada CV. Lakitan Padang sebanyak 35 orang. 
Sampel adalah bagian dari jumlah dan karakteristik yang dimiliki oleh populasi tersebut (Sugiyono, 2012). Jadi metode pengambilan sampel dalam penelitian ini adalah metoda sensus yaitu teknik sampling dimana semua anggota populasi dijadikan sebagai sampel.

Sumber data penelitian ini terdiri atas : 1.Sumber data primer yaitu data yang dikumpulkan langsung dari responden. Adapun data primer yang digunakan dalam penelitian ini adalah data yang didapat dari penyebaran kuisioner kepada responden yang berkenaan dengan data komitmen organisasi, kompensasi dan , kepuasan kerja

2. Sumber data sekuder yaitu meliputi semua data-data dari sumber lain yang berhubungan dengan penelitian ini meliputi tinjauan literatur.

Data dalam penelitian ini menggunakan data primer yang dikumpulkan dengan field survey yaitu dengan mengajukan daftar pertanyaan berupa kuisioner kepada responden. Responden yang dipilih adalah karyawan yang bekerja pada CV. Lakitan. Pengambilan data dilakukan dengan cara memberikan kusioner secara langsung kepada responden. Pengisian kuisioner diusahakan hanya memakan waktu 15 menit sehingga tidak begitu menyita waktu responden.

Adapun variabel yang dipakai dalam penelitian ini adalah :

Variabel independen (variabel bebas) yaitu

- Komitmen organisasi ( X1 ) yang terdiri dari ( Zurnali ,2010) :

1. Komitmen afektif (affective commitment), yaitu: keterlibatan emosional seseorang pada organisasinya berupa perasan cinta pada organisasi.

2. Komitmen kontinyu (continuance commitment), yaitu: persepsi seseorang atas biaya dan resiko dengan meninggalkan organisasi saat ini. Artinya, terdapat dua aspek pada komitmen kontinyu, yaitu: melibatkan pengorbanan pribadi apabila meninggalkan organisasi dan ketiadaan alternatif yang tersedia bagi orang tersebut.

3. Komitmen normatif (normative commitment) ), yaitu: sebuah dimensi moral yang didasarkan pada perasaan wajib dan tanggung jawab pada organisasi yang mempekerjakannya.

- Kompensasi ( X2 ) yang terdiri dari ( Sutrisno, 2011) :

1. Adanya azaz keadilan, Karyawan menerima kompensasi sesuai dengan kemampuannya

2. Adanya Penghargaan, Perusahaan memberikan penghargaan kepada karyawan sesuai dengan kinerjanya.

3. Adanya Kemapuan membayar oleh persusahaan sesuai dengan kemampuan karyawan.

Dependent variable (variabel terikat) yaitu tingkat kepuasan kerja yang disimbolkan dengan Y. yang terdiri dari ( Luthans, 2005) :

1) Pekerjaan itu sendiri, yang termasuk pekerjaan yang memberikan kepuasan adalah pekerjaan yang menarik dan menantang, pekerjaan yang tidak membosankan, sertapekerjaan yang dapat memberikan status.

2) Upah/gaji, Upah dan gaji merupakan hal yang signifikan, namun merupakan factor yang kompleks dan multidimensi dalam kepuasan kerja.

3) Promosi, Kesempatan dipromosikan nampaknya memiliki pengaruh yang beragam terhadap kepuasan kerja, karena promosi 
bisa dalam bentuk yang berbedabeda dan bervariasi pula imbalannya.

4) Supervisi, Supervisi merupakan sumber kepuasan kerja lainnya yang cukup penting pula.

5) Kelompok kerja, Pada dasarnya, kelompok kerja akan berpengaruh pada kepuasan kerja.

Rekan kerja yang ramah dan kooperatif merupakan sumber kepuasan kerja bagi karyawan.

6) Kondisi kerja/lingkungan kerja, Jika kondisi kerja bagus (lingkungan sekitar bersih dan menarik) misalnya, maka pegawai akan lebih bersemangat mengerjakan pekerjaan mereka,namun bila kondisi kerja rapuh (lingkungan sekitar panas dan berisik) misalnya, pegawai akan lebih sulit menyelesaikan pekerjaan mereka.

Metoda analisis yang digunakan adalah regresi linier berganda metoda ini digunakan untuk mengetahui ada atau tidaknya pengaruh antara variabel independen dengan variabel dependen. Analisis regresi berganda dilakukan dengan menggunakan komputer. Perangkat lunak yang digunakan adalah SPSS for windows Release 12 (Singgih, 2005). Maka dapat dirumuskan persamaan regresi berganda yang dikemukakan oleh Gujarati (1997) sebagai berikut:

$$
\mathrm{Y}=\mathrm{a}+\mathrm{b}_{1} \mathrm{X}_{1}+\mathrm{b}_{2} \mathrm{X}_{2}+\mathrm{e}
$$

Dimana :

$\mathrm{Y}=$ Kepuasan karyawan

$\mathrm{a}=$ Konstanta

$\mathrm{X}_{1}=$ Komitmen Organisaasi

$\mathrm{X}_{2}=$ Kompensasi

$\mathrm{E}=$ Tingkat kesalahan

\section{Uji t-statistik}

Bertujuan untuk menguji pengaruh secara parsial antara variabel independen terhadap varaibel dependen dengan variabel lain dianggap konstan, dengan asumsi jika signifikan nilai $t$ hitung yang dapat dilihat dari hasil analisa regresi berganda menujukkan besar dari $\alpha=5 \%$ berarti terdapat pengaruh antara variabel independen terhadap variabel dependen ( Sugiyono, 2005) :

$$
\text { thitung }=\frac{\beta n}{\mathrm{~S} \beta n}
$$

Dimana :

$\mathrm{t}=$ mengikuti fungsi $\mathrm{t}$ dengan derajat kebebasan (df), $\mathrm{n}=\mathrm{k}-1$

$\beta \mathrm{n}=$ koefisien regersi masing-masing variabel

$\mathrm{S} \beta \mathrm{n}=$ standar error masing-masing variable

\section{Uji F-stastistik}

Bertujuan untuk menentukan signifikansi pengaruh variabel independen bersama-sama terhadap variable dependen ( Sugiyono, 2005) dengan rumus :

Dimana :

$$
\mathrm{F}=\frac{\mathrm{R}^{2} /(\mathrm{K}-1)}{\left(1-\mathrm{R}^{2}\right)(\mathrm{n}-\mathrm{k})}
$$

$\mathrm{R}^{2}=$ Koefisien determinan

$\mathrm{n}=$ Jumlah baris

$\mathrm{k}=$ Banyak variable

\section{PEMBAHASAN}

Adapun hasil dari pengujian dengan menggunakan regersi linear berganda adalah sebagai berikut :

$\mathrm{Y}=2,172+0,089 \mathrm{X} 1+0,078 \mathrm{X} 2$

Dimana :

$\mathrm{Y}=$ Kepuasan Pasien

$\mathrm{X} 1=$ Komitmen Organisasi

$\mathrm{X} 2=$ Komitmen

\section{Uji F-Statistik}

Uji F Statistik dilakukan untuk melihat apakah variable independent secara bersama-sama mempunyai pengaruh yang signifikan terhadap variabel dependen dengan pengujian hipotesis sebagai berikut (Singgih, 2005) :

Ho : Variabel independen secara bersama-sama tidak berpengaruh positif dan signifikan terhadap variable dependen.

H1 : Variabel independent secara bersama-sama berpengaruh 
positif dan signifikan terhadap variable dependen.

Apabila F hitung < F table maka Ho diterima artinya variable independent secara bersama-sama tidak berpengaruh positif dan signifikan terhadap variable dependen, begitu sebaliknya apabila $\mathrm{F}$ hitung > F table maka Ho ditolak artinya variable dependen secara bersama-sama berpengaruh positif dan signifikan terhadap variable dependen.

Berdasarkan hasil perhitungan maka terlihat bahwa $\mathrm{F}$ hitung adalah sebesar 6,604 Dengan tingkat signifikansi 0,000 . Sedangkan F table adalah 2,27. Hal ini menunjukkan bahwa $\mathrm{F}$ hitung $>\mathrm{F}$ table sehingga Ho ditolak artinya, secara bersama-sama variabel komitmen organisasi dan kompensasi memiliki pengaruh terhadap kepuasan kerja

\section{Uji t- Statistik}

\section{Komitmen Organisasi}

Dalam melakukan pengujian hipotesis variabel komitmen organisasi dengan uji $t$, maka hipotesa yang dibuat adalah :

H1 : Komitmen Organisasi mempunyai pengaruh positif dan signifikan terhadap kepuasan karyawan

Dasar pengambilan keputusan adalah $\mathrm{t}$ hitung $<\mathrm{t}$ table maka Ho diterima, artinya variable independent secara bersama-sama tidak berpengaruh signifikan terhadap variable dependen, begitu sebaliknya apabila $t$ hitung $>t$ table maka Ho ditolak, artinya variable dependen secara bersama-sama berpengaruh signifikan terhadap variable dependen.

Berdasarkan analisis maka diperoleh bahwa $\mathrm{t}$ hitung adalah sebesar 2,903 sedangkan nilai $t$ table adalah sebesar 1,960. Dengan demikian $t$ hitung $>$ dari t table sehingga Ho ditolak, artinya komitmen Organisasi bepengaruh positif dan signifikan terhadap kepuasan karyawan.

\section{b. Kompensasi}

Dalam melakukan pengujian hipotesis variabel komitmen organisasi dengan uji $t$, maka hipotesa yang dibuat adalah :

H2 : Kompensasi mempunyai pengaruh positif dan signifikan terhadap kepuasan karyawan

Dasar pengambilan keputusan adalah $\mathrm{t}$ hitung $<\mathrm{t}$ table maka Ho diterima, artinya variable independent secara bersama-sama tidak berpengaruh signifikan terhadap variable dependen, begitu sebaliknya apabila $\mathrm{t}$ hitung $>\mathrm{t}$ table maka Ho ditolak, artinya variable dependen secara bersama-sama berpengaruh signifikan terhadap variable dependen.

Berdasarkan analisis maka diperoleh bahwa thitung adalah sebesar 2, 559 sedangkan nilai $t$ table adalah sebesar 1,960. Dengan demikian t hitung $>$ dari $t$ table sehingga Ho ditolak, artinya Kompensasi bepengaruh positif dan signifikan terhadap kepuasan karyawan.

\section{KESIMPULAN}

Kesimpulan yang dapat diperoleh dari penelitian ini adalah sebagai berikut;

a. Variabel Komitmen Organisasi memiliki pengaruh positif $(\beta=0,089)$ dan signifikan $(\alpha=0,019)$ terhadap kepuasan karyawan. Adapun atribut-atribut dari variabel ini adalah sebagai berikut:

1) Pekerjaan itu sendiri, yang termasuk pekerjaan yang memberikan kepuasan adalah pekerjaan yang menarik dan menantang, pekerjaan yang tidak membosankan, sertapekerjaan yang dapat memberikan status.

2) Upah/gaji, Upah dan gaji merupakan hal yang signifikan, namun merupakan factor yang kompleks dan multidimensi dalam kepuasan kerja.

3) Promosi, Kesempatan dipromosikan nampaknya memiliki pengaruh yang beragam terhadap kepuasan kerja, karena promosi 
bisa dalam bentuk yang berbedabeda dan bervariasi pula imbalannya.

4) Supervisi, Supervisi merupakan sumber kepuasan kerja lainnya yang cukup penting pula.

5) Kelompok kerja, Pada dasarnya, kelompok kerja akan berpengaruh pada kepuasan kerja.

Rekan kerja yang ramah dan kooperatif merupakan sumber kepuasan kerja bagi karyawan.

6) Kondisi kerja/lingkungan kerja, Jika kondisi kerja bagus (lingkungan sekitar bersih dan menarik) misalnya, maka pegawai akan lebih bersemangat mengerjakan pekerjaan mereka,namun bila kondisi kerja rapuh (lingkungan sekitar panas dan berisik) misalnya, pegawai akan lebih sulit menyelesaikan pekerjaan mereka.

b. Variabel Kompensasi memiliki pengaruh positif $(\beta=0,078)$ dan signifikan $(\alpha=0,028)$ terhadap kepuasan karyawanAtribut-atribut dari dimensi ini adalah sebagai berikut :

1. Komitmen afektif (affective commitment), yaitu: keterlibatan emosional seseorang pada organisasinya berupa perasan cinta pada organisasi.

2. Komitmen kontinyu (continuance commitment), yaitu: persepsi seseorang atas biaya dan resiko dengan meninggalkan organisasi saat ini. Artinya, terdapat dua aspek pada komitmen kontinyu, yaitu: melibatkan pengorbanan pribadi apabila meninggalkan organisasi dan ketiadaan alternatif yang tersedia bagi orang tersebut.

3. Komitmen normatif (normative commitment) ), yaitu: sebuah dimensi moral yang didasarkan pada perasaan wajib dan tanggung jawab pada organisasi yang mempekerjakannya.

\section{DAFTAR PUSTAKA}

10.22202/economica.2013.v1.i2.117

As'ad, Muh. 2002. Seri Ilmu Sumber Daya Manusia: Psikologi Industri. Yogyakarta. Liberty

Cut Zurnali, 2010, "Learning Organization, Competency, Organizational Commitment, dan Customer Orientation: Knowledge Worker Kerangka Riset Manajemen Sumberdaya Manusia di Masa Depan", Penerbit Unpad Press, Bandung

Dessler, Gary. 2000. Human Resource Management 8th Edition. New Jersey: Prentice-Hall, Inc

Hasibuan, Malayu S.P2005. Manajemen sumber daya manusia. , Jakarta: Bumi Aksara

Luthans, Fred. 2002. Organizational Behavior. New York: McGraw-Hill Company

Robbins.S.P.2007.Manajemen.Penerbit : Erlangga. Jakarta

Rivai, H. Veithzal. 2005. Manajemen Sumber Daya Manusia Untuk Perusahaan:Dari Teori Ke Praktek. Jakarta. PT Raja Grafindo Persada

Simamora, Henry. 2004. Manajemen Sumber Daya Manusia. Yogyakarta: SIE YKPN

Sugiyono.2012.Metode Penelitian Kualitatif dan Kuantitatif.Bandung: CV Alfabeta

Sutrisno, Edy.2011. Manajemen Sumber Daya Manusai.Penerbit : PT.Rineka.Jakarta 